\title{
A comparison of the chemical composition of mixed bacteria harvested from the liquid and solid fractions of rumen digesta
}

\author{
BY R. J. MERRY AND A. B. MCALLAN \\ National Institute for Research in Dairying, Shinfield, Reading, Berkshire RG2 9AT
}

(Received 16 February 1983-Accepted 23 June 1983)

1. Steers, equipped with simple rumen cannulas, were given diets of approximately equal parts of rolled barley and straw supplemented with urea. The diets provided sufficient estimated rumen degradable nitrogen (RDN; $\mathrm{RDN}$ : metabolizable energy values of $1: 3$ ) to maintain maximum microbial synthesis. In some experiments $\mathrm{Na}_{2}{ }^{35} \mathrm{SO}_{4}$ was introduced into the rumen to label microbial protein.

2. Rumen digesta samples were taken before feeding and mixed rumen bacteria were separated from the solid (solid-associated bacteria; SAB) and liquid (liquid-associated bacteria; LAB) fractions of digesta. The most effective method of removing SAB from the fibre was a combination of homogenizing and pummelling. This process did not affect the physical form or chemical composition of the bacteria.

3. Samples of SAB contained significantly $(P \leqslant$ at least 0.05$)$ less ash, total N, RNA and diaminopimelic acid (DAP) and significantly $(P \leqslant 0.01)$ more lipid than samples of LAB. Concentrations $(\mathrm{g} / \mathrm{kg}$ dry matter) of ash, total N, RNA, DAP and lipid in SAB were approximately $87,70,35,2.2$ and 245 respectively. Corresponding values for $\mathrm{LAB}$ were $157,80,50,3 \cdot 8$ and 124 respectively.

4. RNA-N:total $\mathrm{N}$ and DAP-N:total N values in SAB were significantly lower than those in LAB $(P \leqslant 0.05$ and 0.02 respectively). ${ }^{35} \mathrm{~S}$ : total $\mathrm{N}$ values were similar in both groups of bacteria. The importance of differences in constituent: total $\mathrm{N}$ values in the two groups of bacteria in relation to their use as indices of microbial protein synthesis is discussed.

The nitrogen-rationing scheme for ruminants proposed by the Agricultural Research Council (1980) relies to a large extent on the ability to estimate microbial protein synthesis and degradability of feed protein in the rumen and the relative contribution of these different protein sources to digesta entering the small intestine. Estimates of microbial protein supply and, in many cases, feed protein degradability are frequently obtained using microbial markers (Hume, 1976; Stern \& Hoover, 1979), which can be either naturally occurring constituents of rumen microbes or radioisotopes incorporated into the cells during growth. Such estimates require a measure of the marker: non-ammonia-N (NAN) value in abomasal or duodenal digesta and in a corresponding sample of mixed rumen bacteria. Bacteria used for establishing marker: NAN values are generally harvested from the liquid fraction of rumen digesta whereas it is well recognized that a significant proportion of the bacteria in the rumen is closely associated with the solid fraction of the digesta (Cheng et al. 1977; Czerkawski, 1979). However, it is tacitly assumed that the chemical compositions, and thus marker:NAN values, are identical in bacteria from both fractions of rumen digesta and that values derived for mixed bacteria separated from the liquid phase of digesta are representative of the total bacterial population leaving the rumen. Several investigators have expressed doubt about this assumption (Smith, 1975; Hume, 1976; Stern \& Hoover, 1979) but no direct in vivo comparisons have been made between solid and liquid-associated bacteria, probably due to the difficulty of isolating good preparations of the former. Czerkawski (1979), working with a continuous in vitro culture system simulating rumen function, has defined three compartments therein which were a free liquid phase, a liquid associated with solid phase and a solid phase. Further work, using the same technique (Czerkawski \& Breckenridge, 1982) showed considerable differences in some metabolites associated with each phase suggesting different metabolic activities in the microbial populations associated with each compartment. 
The present experiments were designed to examine possible methods of isolating solid-associated bacteria, to compare the chemical compositions of such bacteria with that of liquid-associated bacteria and to assess what effects any differences would have on the quantitative estimation of rumen microbial protein synthesis.

A preliminary report of this work has been published elsewhere (Merry \& McAllan, 1983).

EXPERIMENT AL

Animals, diets and the collection of digesta

Four Friesian steers weighing 140-180 kg, each equipped with a cannula in the dorsal sac of the rumen, were used. The rumen cannulas were as described by Smith \& McAllan (1970) except that the internal diameters were $50 \mathrm{~mm}$.

The steers were given diets consisting of rolled barley, barley straw and urea at dry matter (DM) intakes of $1.3,1.4$ and $0.018 \mathrm{~kg} / \mathrm{d}$ respectively. These amounts were given initially to steers weighing between $140-160 \mathrm{~kg}$ and were increased by approximately $15 \%$ for every $20 \mathrm{~kg}$ increase in live weight. The diets contained $15.4 \mathrm{~g} \mathrm{~N}$ and $10.4 \mathrm{MJ}$ metabolizable energy (ME) $/ \mathrm{kg} \mathrm{DM}$ and were given at a level calculated to maintain $0.25 \mathrm{~kg}$ weight gain $/ \mathrm{d}$ (Ministry of Agriculture, Fisheries and Food, 1977). Rumen-degradable N (RDN): ME was $1 \cdot 3$, estimated to be greater than that required for maximum microbial growth (Agricultural Research Council, 1980). The feeds were given in two equal portions at 09.00 and 17.00 hours daily.

Prefeed samples (3.51) of rumen digesta were removed from the ventral sac of the rumen by suction through a perforated tube (internal diameter $20 \mathrm{~mm}$ ). This sample was supplemented with approximately $1 \mathrm{~kg}$ of the fibrous mat of digesta above the semi-liquid layer, which was taken with tongs inserted through the cannula. The total sample, referred to as whole rumen contents, was used to separate bacteria associated with the liquid fraction (LAB) and solid fraction (SAB) of digesta.

In some experiments, over a $10 \mathrm{~d}$ period before sampling, $100 \mathrm{ml}$ of a solution containing $0.6 \mathrm{~g}$ sodium sulphate and $320 \mu \mathrm{Ci}^{35} \mathrm{~S}_{\text {as }} \mathrm{Na}_{2}{ }^{35} \mathrm{SO}_{4}$ (Amersham International, Amersham, Bucks) was introduced directly into the rumen of two steers at each feed.

At the end of the experiments the two steers that had been dosed with $\mathrm{Na}_{2}{ }^{35} \mathrm{SO}_{4}$ were killed by injecting an overdose of sodium pentobarbitone solution $(100 \mathrm{mg} / \mathrm{kg}$ body-weight). The entire contents of the reticulo-rumen were removed and strained through four layers of surgical gauze. The relative amounts of liquor (digesta passing through the gauze) and solid (digesta retained by the gauze) were recorded and the DM contents determined.

\section{Removal of bacteria from the solid fraction of digesta}

Whole rumen contents ( 31 ) were strained through four layers of surgical gauze and the solid material remaining (subsequently referred to as the fibre) was divided into twelve portions. Samples (30 $\mathrm{g}$ in duplicate) were suspended with mixing in $150 \mathrm{ml}$ of the appropriate solutions (see treatments below) and one sample from each group was homogenized for 3 min (speed 2, Braun Blender MX32; Braun AG, Frankfurt). The pairs of samples (homogenized and unhomogenized) were then subjected to the following treatments:

Cooling and detergent. Samples suspended in a solution of Tween 80 in saline $(9 \mathrm{~g}$ sodium chloride $/ \mathrm{l} ; 10 \mathrm{ml} / 1)$ were cooled at $4^{\circ}$ for $6 \mathrm{~h}$ according to the procedure of Dehority \& Grubb (1980).

Sodium metaperiodate. Samples suspended in a solution of $0.2 \mathrm{M}$-sodium metaperiodate in $0.1 \mathrm{M}$-sodium acetate buffer, $\mathrm{pH} 4.0$, were incubated at $37^{\circ}$ for $30 \mathrm{~min}$ as described by Latham et al. (1978).

Pepsin. Samples suspended in a solution of pepsin $(0.2 \mathrm{mg} / \mathrm{ml})$ in $0.045 \mathrm{M}$-citric acid-

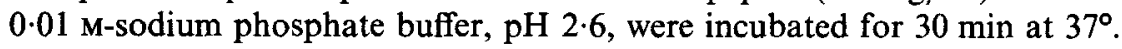


Mechanical pummelling. Samples in a solution of saline were placed in thick-walled polyethylene bags $(180 \times 300 \mathrm{~mm})$ and subjected to vigorous mechanical pummelling between two metal plates for $5 \mathrm{~min}$ in a Colworth Stomacher 400 (A. J. Seward \& Co. Ltd, London). This treatment is subsequently referred to as stomaching.

Mercuric chloride. Samples in a solution of saline containing $5 \mu \mathrm{g}$ mercuric chloride $/ \mathrm{ml}$ were incubated at $37^{\circ}$ for $30 \mathrm{~min}$.

Sodium chloride. Samples were mixed in a solution of saline.

After each of the treatments, the samples were strained through surgical gauze. The fibres were resuspended in saline $(100 \mathrm{ml})$, mixed, and strained again. The wash procedure was repeated once more. The treated fibre samples together with an untreated, unwashed fibre sample $(30 \mathrm{~g})$ were freeze-dried and stored for subsequent analysis.

When examination by scanning electron microscopy was intended, 'tagged' (marked with coloured threads) lengths of fibre (10-mm portions cut from a single length of untreated fibre) were included with each of the previously-described treatments. Comparisons were made with untreated sections from the same length of fibre.

\section{Harvest of $L A B$ and $S A B$ from rumen digesta}

Samples of whole rumen contents were taken from four steers and strained through surgical gauze. LAB were harvested from the liquid fraction by differential centrifugation according to Smith \& McAllan (1974). In order to dislodge SAB, samples (250-375 g) of fibre were suspended in saline ( $320 \mathrm{ml} / 100 \mathrm{~g}$ fibre), homogenized, stomached and washed as described previously. Washings consisted of $100 \mathrm{ml}$ saline $/ 100 \mathrm{~g}$ fibre. The filtrate and washings were combined and SAB were harvested according to the procedure of Smith \& McAllan (1974).

Samples of treated and untreated fibre, LAB and SAB were immediately extracted according to the procedure of McAllan \& Smith (1969) in preparation for the analysis of RNA. The remainders were freeze-dried for subsequent analysis.

\section{Effect of physical treatment on bacterial appearance and composition}

Whole rumen contents ( 31 ) were strained through surgical gauze and 11 of the filtrate was homogenized and stomached in $250 \mathrm{ml}$ amounts as described previously. Bacteria were harvested from the treated sample and also from 11 of the untreated filtrate and immediately extracted in preparation for the analysis of RNA. The remainders of the samples were freeze-dried for subsequent analysis.

\section{Analytical methods}

DM was determined by freeze-drying to constant weight. Ash was determined after heating freeze-dried samples at $520^{\circ}$ for $18 \mathrm{~h}$ in a muffle furnace. Total $\mathrm{N}$ was determined as described by Smith \& McAllan (1970) and $\alpha-\epsilon$-diaminopimelic acid (DAP) by the method of Smith et al. (1978), except that the ion-exchange resin used was Duolite C225, SRC 15, 10-200 mesh (British Drug Houses, Poole, Dorset) and a flow-rate of $30 \mathrm{ml} / \mathrm{h}$. RNA analyses were carried out according to the procedure of McAllan \& Smith (1969) and total and nucleic acid phosphorus by the procedures of Merry et al. (1982). Lipid in freeze-dried bacterial samples was extracted with a chloroform-methanol mixture $(2: 1, \mathrm{v} / \mathrm{v})$ as described by Folch et al. (1957), dried and total lipid determined gravimetrically. ${ }^{35} \mathrm{~S}$ was determined by the method of Mathers \& Miller (1980). Samples of bacteria were subjected to acid hydrolysis (McAllan \& Smith, 1974) which released rhamnose, ribose, galactose arabinose, xylose and $\alpha$-linked glucose (starch-glucose). Amounts of these sugars were determined by ion-exchange chromatography of their borate complexes (McAllan \& Smith, 1974).

Lengths of treated and untreated 'fibre' (see above) for scanning electron microscopy 
were prefixed in glutaraldehyde in $0.2 \mathrm{M}$-sodium phosphate buffer, $\mathrm{pH} 7 \cdot 2(30 \mathrm{~g} / 1)$ for $1.5 \mathrm{~h}$. This treatment was followed by post-fixing in osmium tetroxide in $0.2 \mathrm{M}$-sodium phosphate buffer $(10 \mathrm{~g} / 1)$ and treatment with thiocarbohydrazide and osmium tetroxide in $0.2 \mathrm{M}$-sodium phosphate buffer $(10 \mathrm{~g} / 1)$ by a modification of the method of Malick \& Wilson (1975). Specimens were dehydrated in a series of acetone-water mixtures and finally absolute acetone and dried in a Polaron E3000 critical point drying apparatus using liquid carbon dioxide. After mounting on a scanning stub using double-sided Sellotape, specimens were coated with gold using an Edwards S150 Sputter Coater. Examination was carried out in an ISA IIIA scanning electron microscope at an accelerating voltage of $25 \mathrm{kV}$. The number of bacteria in ten randomly selected fields at $\times 5000$ magnification was counted.

Bacterial preparations for transmission electron microscopy were fixed in glutaraldehyde in Hepes buffer, $\mathrm{pH} 7 \cdot 2(30 \mathrm{~g} / \mathrm{l})$ for $1 \mathrm{~h}$ and suspended in Agar. This was followed by washing in Hepes buffer, $\mathrm{pH} 7.2$ and post-fixing in osmium tetroxide in $0.2 \mathrm{M}$-sodium phosphate buffer, $\mathrm{pH} 7 \cdot 2(10 \mathrm{~g} / \mathrm{l})$ for $1 \mathrm{~h}$. The post-fixative was decanted and heated with aqueous uranyl acetate $(10 \mathrm{~g} / \mathrm{l})$ for $0.5 \mathrm{~h}$ followed by dehydration in a series of acetone-water mixtures ending with absolute acetone. The prepared samples were then embedded in Araldite. Sections were cut using a Reichert OM U3 ultramicrotome, stained in lead citrate (Reynolds, 1963) and examined in a Hitachi 600 transmission electron microscope at an accelerating voltage of $75 \mathrm{kV}$.

Tests of significance were carried out by the paired $t$ test procedure of Snedecor \& Cochran (1972).

\section{RESULTS}

\section{Removal of $S A B$ from the solid fraction of rumen digesta}

The effectiveness of the different procedures used to remove bacteria from fibre was determined by estimating the amount of DAP removed, assuming that all the DAP in the fibre sample was bacterial in origin. All six treatments employed were successful in dislodging SAB to varying extents and results are presented in Table 1. The inclusion of an initial homogenizing treatment resulted in all cases in increased removal of SAB from the fibre. The most effective treatment over-all was the combination of homogenizing and stomaching where approximately $76 \%$ of the DAP was removed from the fibre. Visual evidence of the effectiveness of this treatment in removing bacteria was provided by SEM of fibre before (Plate $1 a$ ) and after (Plate $1 b$ ) homogenizing and stomaching.

The proportion of bacteria removed from the fibre by homogenizing and stomaching was also measured in the experiments where bacteria were harvested. The results are for two animals only (those infused with ${ }^{35}$ S) but values obtained for RNA and DAP from the other animals were very similar. The procedure removed 72,32 and $65 \%$ of DAP, RNA and ${ }^{35} \mathrm{~S}$ respectively from the original material.

Fractionation of total rumen contents from the steers dosed with $\mathrm{Na}_{2}{ }^{35} \mathrm{SO}_{4}$ gave mean values (with SE) for total liquid volume in the solid and liquid fractions of $8.32(0.22)$ and $12.40(1.80) 1$ respectively and corresponding DM contents of $2.50(0.16)$ and $0.56(0.02) \mathrm{kg}$.

\section{Effect of physical treatments on bacterial appearance and composition}

In order to determine whether mechanical treatment such as that used to prepare SAB had any effect on bacterial composition and physical structure, comparisons were made between bacteria before and after treatment. As it was impossible to study this with SAB, LAB were harvested for this purpose and it was assumed that any adverse effect of treatment would apply equally to $\mathrm{SAB}$ as well as $\mathrm{LAB}$.

No marked differences were observed in the composition or the RNA-N or DAP-N: total $\mathrm{N}$ relationships between bacterial samples prepared from untreated rumen fluid and those separated after homogenizing and stomaching procedures (Table 2). Visual inspection of transmission electron micrographs showed that in samples separated after mechanical 
Table 1. Proportions of $\alpha-\epsilon-$ diaminopimelic acid $(D A P)$ removed from the fibre fraction of steer rumen contents with or without homogenizing and after various treatments

(Results are mean values for two animals and are expressed as the proportion of DAP removed relative to that in an untreated sample)

\begin{tabular}{lcc}
\hline \multicolumn{1}{c}{ Treatment* } & $\begin{array}{c}\text { With } \\
\text { homogenizing }\end{array}$ & $\begin{array}{c}\text { Without } \\
\text { homogenizing }\end{array}$ \\
\hline Stomaching & 0.77 & 0.70 \\
Incubation in mercuric chloride at $37^{\circ}$ & 0.68 & 0.48 \\
Incubation in pepsin at $37^{\circ}$ & 0.65 & 0.55 \\
Incubation in sodium metaperiodate at 37 & 0.52 & 0.22 \\
Incubation in Tween at 4 & 0.65 & 0.49 \\
Sodium chloride washing & 0.51 & 0.36 \\
\hline \hline
\end{tabular}

* For details, see pp. 702 and 703.

Table 2. Concentrations ( $\mathrm{g} / \mathrm{kg}$ dry matter) of total nitrogen, $\alpha-\epsilon$-diaminopimelic acid (DAP) and $R N A$ in samples of mixed rumen bacteria separated from the liquid fraction of untreated rumen fluid or after rumen fluid had been subjected to homogenizing and stomaching*; also $R N A-N$ : total $N$ and $D A P-N$ : total $N$ values

\begin{tabular}{lccccc}
\hline \multicolumn{1}{c}{ Source of bacteria } & Total N & DAP & RNA & RNA-N:total N & $\begin{array}{c}\text { DAP-N:total N } \\
\left(\times 10^{-3}\right)\end{array}$ \\
\hline Untreated fluid & 94.7 & 4.07 & 53.4 & 0.084 & 6.41 \\
Homogenized and stomached fluid & 96.0 & 4.40 & 58.8 & 0.091 & 6.79 \\
\hline \hline
\end{tabular}

* For details, see p. 703.

treatment of rumen fluid the bacterial cells were intact and there was little trace of contamination by feed debris. That the samples of SAB were relatively uncontaminated with fibrous feed particles was confirmed by the presence of only very small amounts of the hemicellulose sugars arabinose and xylose of approximately 3.1 and $5 \cdot 1 \mathrm{~g} / \mathrm{km}$ DM respectively. Corresponding values for these sugars in LAB samples were 3.2 and $2.8 \mathrm{~g} / \mathrm{kg}$ DM. Some of the mannose and galactose found in the bacterial separations may also have been of dietary origin (Table 3). However, the ratios xylose: mannose and xylose: galactose in straw are high (100:1 and 12:1 respectively; McAllan \& Smith, 1976b) and it can be calculated that less than $4 \%$ of the mannose and galactose measured in the bacterial separations are likely to be feed contaminants.

\section{Chemical composition of $L A B$ and $S A B$}

The amounts of different constituents found in LAB and SAB (one analysis for each of four steers) are presented in Table 3. The concentrations of ash, total N, RNA and DAP were all significantly lower $(P$ at least $\leqslant 0.05)$ in $\mathrm{SAB}$ compared with LAB whereas the lipid content was significantly higher $(P \leqslant 0 \cdot 01)$. Total $P$, nucleic acid-P, ${ }^{35} S$ and total carbohydrate contents were also lower in SAB than LAB but these values were from only two animals and no tests of significance were done.

Although total N, RNA and DAP concentrations were all lower in SAB than in LAB, the values for RNA-N:total N and DAP-N: total $N$ were still significantly lower in SAB than in $\mathrm{LAB}\left(P \leqslant 0.05\right.$ and 0.02 respectively). ${ }^{35} \mathrm{~S}$ : total $\mathrm{N}$, however, was similar in both types of bacteria. 
Table 3. Concentrations $(\mathrm{g} / \mathrm{kg}$ dry matter $(D M))$ of total lipid, ash, total nitrogen, RNA, $\alpha-\epsilon$-diaminopimelic acid (DAP), total phosphorus $(P)$, nucleic acid-P $(N A-P)$ and carbohydrate of mixed bacteria separated from the liquid (liquid-associated bacteria; LAB) and solid (solid-associated bacteria; $S A B$ ) fractions of rumen digesta from steers; also specific activities (disintegrations/min per $g D M$ ) of ${ }^{35} S$ and constituent : total $N$ values

(Results are mean values with their standard errors for a single analysis from four steers unless otherwise stated)

\begin{tabular}{|c|c|c|c|c|}
\hline & \multicolumn{2}{|c|}{ LAB } & \multicolumn{2}{|c|}{$\mathrm{SAB}$} \\
\hline & Mean & $\mathrm{SE}$ & Mean & SE \\
\hline Total lipid & $124 \cdot 4$ & $8 \cdot 2$ & $244 \cdot 5^{* *}$ & 8.7 \\
\hline Ash & $157 \cdot 1$ & $20 \cdot 2$ & $86.6 \dagger$ & $2 \cdot 4$ \\
\hline Total N & $80 \cdot 3$ & $2 \cdot 6$ & $70 \cdot 1^{*}$ & $2 \cdot 8$ \\
\hline RNA & $50 \cdot 3$ & $1 \cdot 3$ & $35 \cdot 4 * * *$ & $2 \cdot 4$ \\
\hline DAP & 3.81 & $0 \cdot 45$ & $2 \cdot 20^{* * *}$ & $0 \cdot 18$ \\
\hline Total P\$ & $12 \cdot 78$ & $2 \cdot 42$ & 9.75 & 1.23 \\
\hline NA-P§ & 9.08 & 0.89 & $7 \cdot 25$ & 0.31 \\
\hline${ }^{35} \mathrm{~S} \S$ & 141.5 & & $112 \cdot 1$ & \\
\hline Rhamnose $\S$ & 12.89 & $4 \cdot 10$ & 6.99 & 1.40 \\
\hline Ribose§ & $7 \cdot 42$ & 0.06 & 3.76 & 0.34 \\
\hline Mannose§ & 3.05 & 0.58 & $3 \cdot 37$ & 0.54 \\
\hline Galactose§ & 12.09 & 0.81 & 8.98 & 1.75 \\
\hline Starch-glucose§ & 22.05 & $5 \cdot 60$ & 26.63 & $10 \cdot 21$ \\
\hline Total carbohydrate $\$$ & $57 \cdot 47$ & $11 \cdot 19$ & $49 \cdot 36$ & $14 \cdot 40$ \\
\hline RNA-N : total N & 0.093 & 0.002 & $0.075 \dagger$ & 0.005 \\
\hline DAP-N: total N $\left(\times 10^{2}\right)$ & $0 \cdot 698$ & 0.067 & $0.469^{*}$ & 0.032 \\
\hline${ }^{35} \mathrm{~S}:$ total N\& & $2 \cdot 11$ & 0.03 & 2.04 & 0.03 \\
\hline Total P:total N\$ & $0 \cdot 167$ & $0 \cdot 031$ & $0 \cdot 149$ & 0.028 \\
\hline NA-P: total N\& & 0.119 & 0.016 & $0 \cdot 110$ & 0.012 \\
\hline
\end{tabular}

Significance of differences between means: $\dagger P \leqslant 0.05,{ }^{*} P \leqslant 0.02,{ }^{* *} P \leqslant 0.01,{ }^{* * *} P \leqslant 0.001$. $\S$ Values from two steers only.

\section{DISCUSSION}

Although stomaching was an effective method for removing SAB from fibre, further improvements were obtained by homogenizing before stomaching, confirming the findings of Warner (1962) that homogenizing of solid material from rumen digesta increased the total cell counts in the liquor. Estimates of the removal of SAB from the fibre in terms of DAP, which is found in many species of bacteria (Synge, 1953) but is absent from feeds (Dufva et al. 1982), or organically-bound ${ }^{35} \mathrm{~S}$ (assumed bound in the bacterial protein) were very similar and showed that in the harvest experiments at least $65 \%$ of the SAB were removed by the procedure employed.

The lipid content of LAB (approximately $120 \mathrm{~g} / \mathrm{kg} \mathrm{DM}$ ) was similar to published values for mixed bacteria from sheep (Czerkawski, 1976; Kurilov et al. 1976), calves (Williams et al. 1963) and cows (Katz \& Keeney, 1964) but was significantly lower than that of the SAB (approximately $245 \mathrm{~g} / \mathrm{kg} \mathrm{DM}$ ) in the present experiments. Hoogenraad \& Hird (1970), however, reported a high lipid content (approximately $260 \mathrm{~g} / \mathrm{kg} \mathrm{DM}$ ) in mixed bacteria separated from rumen digesta of sheep on all-roughage diets. It is known that bacteria grown in high-acetate concentrations accumulate large amounts of lipid (Luria, 1960) and local concentrations of acetate trapped around SAB in the fibre matrix may have been substantially higher than in the liquid fraction of the digesta (Czerkawski \& Breckenridge, 1982). The differences found in the lipid contents of SAB and LAB may help to explain the apparent net increase in lipid found between the mouth and duodenum of sheep which 
could not be explained in terms of the feed lipid intake plus microbial lipid flow calculated using the lipid content of bacteria harvested from the liquid fraction of digesta (Knight, 1980).

The marked difference found in lipid, ash, total $N$ and RNA contents of SAB compared with LAB may reflect different stages of growth and nutrition of particular populations as well as varying bacterial compositions of the different populations (Smith \& McAllan, 1974; Czerkawski, 1976; McAllan \& Smith, 1976a, Czerkawski \& Breckenridge, 1982). The presence of protozoa is known to affect bacterial numbers and patterns of fermentation (Demeyer \& Van Nevel, 1979; Demeyer, 1981) and although not investigated in present work these effects may have been greater on SAB if protozoa were more closely associated with the solid rather than liquid fraction of digesta.

The lower DAP content of mixed SAB compared with mixed LAB found in the present experiments is not surprising. DAP is not present in the cell walls of Gram-positive cocci (Work \& Dewey, 1953) which form an appreciable proportion of the bacteria associated with plant cell-wall material in the rumen (Minato et al. 1966; Latham, 1980). Grampositive species have also been found to form a greater proportion of the total rumen bacterial population in cattle receiving high-roughage diets compared with high-concentrate diets (Nagaraja et al. 1978). It must be borne in mind that mixed bacteria separated from either the solid or liquid fractions of digesta are very loosely defined in the present experiments. Estimates based on the liquid content of the fibre fraction and the amount of DAP in strained rumen fluid (assuming that this fraction is representative of liquid associated with the fibre) indicate that approximately $30 \%$ of the bacteria associated with the solid phase may strictly have been LAB. This was for digesta from animals receiving approximately equal proportions of roughage and concentrates, where the contribution of SAB and LAB to the total bacterial population was approximately $50: 50$. Thus crosscontamination of samples of SAB or LAB could vary depending on the type of diet and on the relative contribution of each group of bacteria to the total population. For example, Dufva et al. (1982) reported that DAP-N: total N values in LAB were lower in digesta from cattle receiving high roughage diets compared with high concentrate diets.

Methods of estimating the efficiency of microbial protein synthesis in vivo rely heavily on marker techniques in which a particular microbial cell constituent is related to the cell $\mathrm{N}$ content. This value is used together with the constituent concentrations in digesta at the abomasum or duodenum to determine the microbial- $\mathrm{N}$ flow at that point and subsequently the efficiency of microbial protein synthesis (Smith et al. 1978). Marker: $N$ values have generally been established in mixed bacteria separated from the liquid fraction of rumen digesta (LAB) and it has been assumed that the same relationship holds in bacteria from other compartments of rumen digesta, and in protozoa, and thus for the total population leaving the rumen. Values found for the efficiency of microbial protein synthesis in different animals receiving a wide variety of diets, vary markedly (Agricultural Research Council, 1980) and results obtained under the same conditions but using different markers may also be quite variable (Siddons et al. 1979, 1982).

In the present experiments RNA-N: total N and DAP-N: total N values were significantly lower in SAB compared with LAB. Arambel et al. (1982) found that the total $\mathrm{N}$ content and RNA-N:total $\mathbf{N}$ and DNA-N:total $\mathrm{N}$ values for pure cultures of Gram-positive bacteria were all less than those found in pure cultures of Gram-negative bacteria. Estimates, based on ${ }^{35} \mathrm{~S}$, showed that in the present work where the steers received diets of approximately equal proportions of roughage and concentrates, approximately half the total bacterial population was associated with the solid fraction of digesta. Under different feeding regimens these proportions may vary markedly. In sheep receiving all-roughage diets (Faichney 1980) and cattle receiving roughage: concentrate diets (Wolstrup \& Jensen, 1978) 
up to 90 and $77 \%$ respectively of the rumen bacteria were associated with the solid fraction of digesta. Thus the contribution of LAB to the total bacteria entering the small intestine could be quite variable. The use of marker ratios established in samples of LAB could result in underestimations of bacterial protein flow and consequently underestimations of the efficiency of bacterial protein synthesis.

Despite differences in ${ }^{35} \mathrm{~S}$ activity and $\mathrm{N}$ content of the two populations of bacteria, the ${ }^{35} \mathrm{~S}$ : total $\mathrm{N}$ values were very similar, suggesting that although the ${ }^{35} \mathrm{~S}$ label may not be uniformly distributed throughout the different microbial populations, its relationship to the $\mathrm{N}$ content of the cells remains fairly constant. If this relationship holds true under other variable conditions mentioned above, it would appear that reliable estimates of microbial protein flow into the small intestine would be obtained using ${ }^{35} \mathrm{~S}$ as the microbial marker.

In the present work no attempts were made to isolate protozoa from either fraction of rumen digesta, although they were present in appreciable numbers (approximately $2 \times 10^{5}$ ). It is generally assumed that marker: $N$ values established in mixed rumen bacteria are applicable to protozoa. However, in the light of the present findings and some reports that RNA: total N values in mixed protozoa are considerably lower than those found in mixed bacteria (Ling \& Buttery, 1978; Tamminga, 1978), and that the numbers and species of protozoa vary with different diets (Hungate, 1966), the need for caution in the application of marker: $\mathbf{N}$ values, however derived, is obvious.

The authors thank Dr H. L. Buttle for the insertion of cannulas, Mrs C. Chard and staff for the care and maintenance of the animals and Mr I. J. Tarr and Mr D. Hooley for skilled assistance. They would also like to thank Mr B. E. Brooker and staff for their valuable co-operation in carrying out scanning electron microscopy on some of the samples prepared in this work.

\section{REFERENCES}

Agricultural Research Council (1980). The Nutrient Requirements of Ruminant Livestock. Slough: Commonwealth Agricultural Bureaux.

Arambel, M. J., Bartley, E. E., Dufva, G. S., Nagaraja, T. G. \& Dayton, A. D. (1982). Journal of Dairy Science 65, 2095-2101.

Cheng, K.-J., Akin, D. E. \& Costerton, J. W. (1977). Federation Proceedings 36, 193-197.

Czerkawski, J. W. (1976). Journal of the Science of Food and Agriculture 27, 621-632.

Czerkawski, J. W. (1979). Annual Report of the Hannah Research Institute, pp. 69-85.

Czerkawski, J. W. \& Breckenridge, G. (1982). British Journal of Nutrition 47, 331-348.

Dehority, B. A. \& Grubb, J. A. (1980). Applied and Environmental Microbiology 39, 376-381.

Demeyer, D. I. (1981). Agriculture and Environment 6, 295-337.

Demeyer, D. I. \& Van Nevel, C. J. (1979). British Journal of Nutrition 42, 515-524.

Dufva, G. S., Bartley, E. E., Arambel, M. J., Nagaraja, T. G., Dennis, S. M., Galitzer, S. J. \& Dayton, A. D. (1982). Journal of Diary Science 65, 1754-1759.

Faichney, G. J. (1980). Australian Journal of Agricultural Research 31, 1129-1137.

Folch, J., Lees, M. \& Sloane Stanley, G. H. (1957). Journal of Biological Chemistry 226, 497-509.

Hoogenraad, N. J. \& Hird, F. J. R. (1970). British Journal of Nutrition 24, 119-127.

Hume, I. D. (1976). Reviews in Rural Science 2, 79-84.

Hungate, R. E. (1966). The Rumen and its Microbes. New York: Academic Press.

Katz, I. \& Keeney, M. (1964). Biochemica et Biophysica Acta. 84, 128-132.

Knight, R. (1980). Rumen lipid synthesis. PhD Thesis, University of Reading.

Kurilov, N. V., Sevastianova, N. A., Korshanov, V. N., Mysnik, N. D. \& Podshibyakin, A. E. (1976). Livestock Production Science 3, 57-63.

Latham, M. J. (1980). In Microbial Adhesion to Surfaces, pp. 339-350 [R. C. W. Berkeley, J. M. Lynch, J. Melling, P. R. Rutter and B. Vincent, editors]. Chichester: Ellis Horwood.

Latham, M. J., Brooker, B. E., Pettipher, G. L. \& Harris, P. J. (1978). Applied and Environmental Microbiology 35, $156-165$.

Ling, J. R. \& Buttery, P. J. (1978). British Journal of Nutrition 39, 165-179.

Luria, S. E. (1960). In The Bacteria, vol. 1, pp, 1-34 [I. C. Gunsalus and R. Y. Stanier, editors]. London: Academic Press.

McAllan, A. B. \& Smith, R. H. (1969). British Journal of Nutrition 23, 671-682.

McAllan, A. B. \& Smith, R. H. (1974). British Journal of Nutrition 31, 77-88. 
McAllan, A. B. \& Smith, R. H. (1976a). Journal of Agricultural Science, Cambridge 86, 639-642.

McAllan, A. B. \& Smith, R. H. (1976b). British Journal of Nutrition 36, 511-522.

Malick, L. E. \& Wilson, R. B. (1975). Stain Technology 50, 265-269.

Mathers, J. C. \& Miller, E. L. (1980). British Journal of Nutrition 43, 503-514.

Merry, R. J. \& McAllan, A. B. (1983). Proceedings of the Nutrition Society 42, 49A.

Merry, R. J., Smith, R. H. \& McAllan, A. B. (1982). British Journal of Nutrition 48, 287-304.

Minato, H., Endo, A., Higuchi, M., Ootomo, Y. \& Uemura, T. (1966). Journal of General and Applied Microbiology, Tokyo 12, 39-52.

Ministry of Agriculture, Fisheries and Food (1977). Energy Allowances and Feeding Systems for Ruminants. Technical Bulletin No. 33, London: HM Stationery Office.

Nagaraja, T. G., Bartley, E. E., Fina, L. R. \& Anthony, H. D. (1978). Journal of Animal Science 47, $1329-1337$.

Reynolds, E. S. (1963). Journal of Cell Biology 17, 208-212.

Siddons, R. C., Beever, D. E. \& Nolan, J. V. (1982). British Journal of Nutrition 48, 377-389.

Siddons, R. C., Beever, D. E., Nolan, J. V., McAllan, A. B. \& MacRae, J. C. (1979). Annales de Recherches Vétérinaires, Paris 10, 286-287.

Smith, R. H. (1975). In Digestion and Metabolism in the Ruminant, pp. 399-415 [I. W. McDonald and A. C. I. Warner, editors]. Armidale, NSW: University of New England Publishing Unit.

Smith, R. H. \& McAllan, A. B. (1970). British Journal of Nutrition 24, 545-556.

Smith, R. H. \& McAllan, A. B. (1974). British Journal of Nutrition 31, 27-34.

Smith, R. H., McAllan, A. B., Hewitt, D. \& Lewis, P. E. (1978). Journal of Agricultural Science, Cambridge 90 , 557-568.

Snedecor, G. W. \& Cochran, W. G. (1972). In Statistical Methods, pp. 91-97. Ames, Iowa: Iowa State University Press.

Stern, M. D. \& Hoover, W. H. (1979). Journal of Animal Science 49, 1590-1603.

Synge, R. L. M. (1953). Journal of General Microbiology 9, 407-409.

Tamminga, S. (1978). In Ruminant Digestion and Feed Evaluation, pp. 5.1-5.13 [D. F. Osbourn, D. E. Beever and D. J. Thomson, editors]. London: Agricultural Research Council.

Warner, A. C. I. (1962). Journal of General Microbiology 28, 119-128.

Williams, P. P., Gutierrez, J. \& Davis, R. E. (1963). Applied Microbiology 11, 260-264.

Wolstrup, J. \& Jensen, K. (1978). Journal of Applied Bacteriology 45, 49-56.

Work, E. \& Dewey, D. L. (1953). Journal of General Microbiology 9, 394-409.

\section{EXPLANATION OF PLATE}

Plate 1. (a) Scanning electron micrograph of partially-digested straw which had been in the rumen for at least $24 \mathrm{~h}$, showing the associated population of bacteria. (b) Scanning electron micrograph of section of partially-digested straw from the same length as in $(a)$ but after homogenizing and stomaching, followed by washing in saline $(9 \mathrm{~g}$ sodum chloride/l). Note the reduction in numbers of associated bacteria compared with (a). 

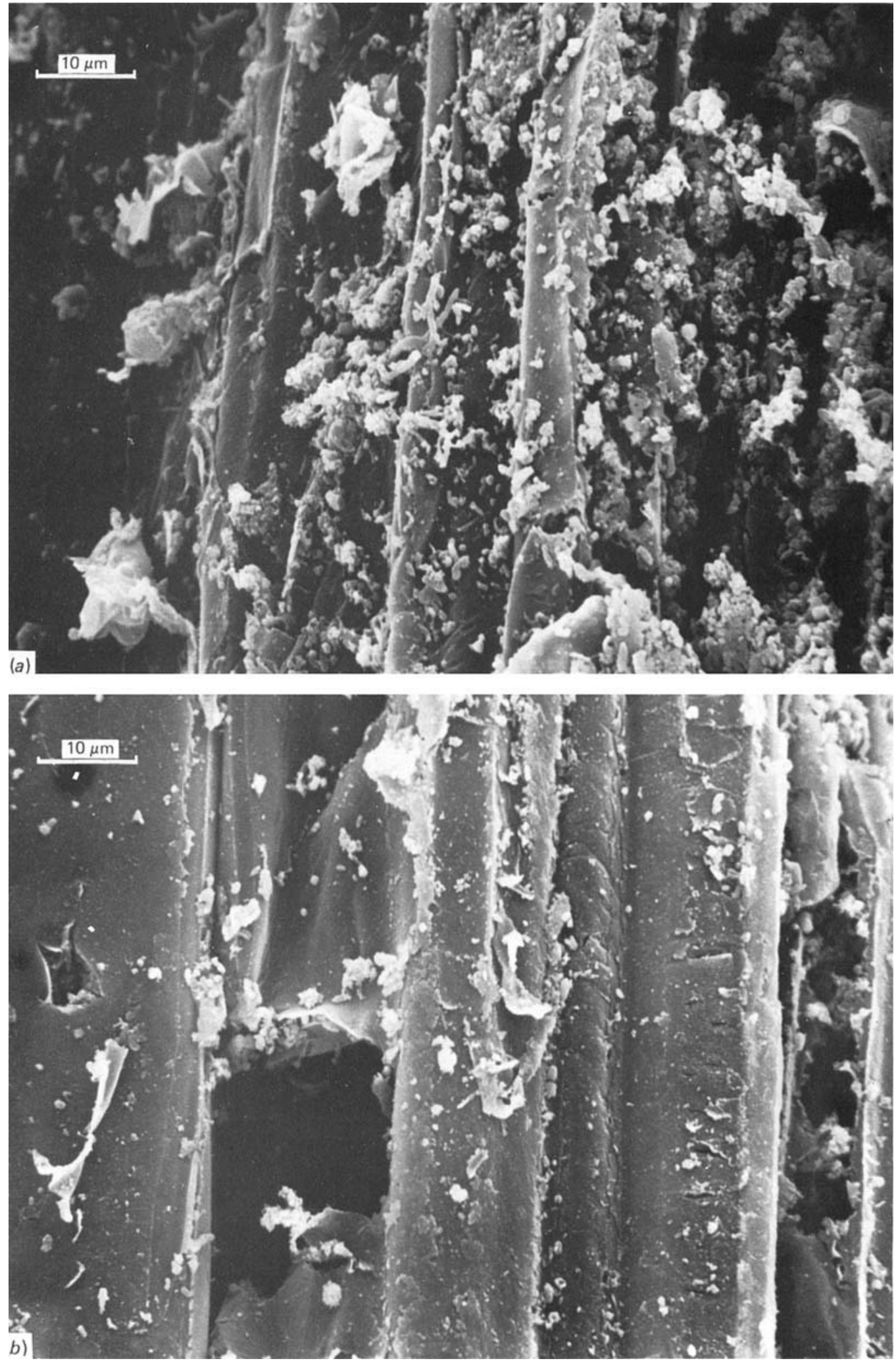